\title{
OPTIMISED SELENIUM ENRICHMENT OF ARTEMIA SP. FEED TO IMPROVE RED DRUM (SCIAENOPS OCELLATUS) LARVAE REARING
}

\author{
Péter Juhász, ${ }^{1 *}$ Szvetlana Lengyel, ${ }^{2}$ Zsolt Udvari, ${ }^{3}$ \\ Alex NAGY SÁNDOR ${ }^{4}$ and LÁsZló STÜNDL ${ }^{1}$ \\ ${ }^{1}$ Faculty of Agricultural and Food Sciences and Environmental Management, Department of Animal \\ Husbandry, University of Debrecen, H-4032 Debrecen, Böszörményi út 138. Hungary \\ ${ }^{2}$ Network of Aquaculture Centres in Central and Eastern Europe, \\ H-5540 Szarvas, Anna-liget 8. Hungary \\ ${ }^{3}$ Ministry of Agriculture, H-1055 Budapest, Kossuth Lajos tér 11. Hungary \\ ${ }^{4}$ Faculty of Science and Technology, University of Debrecen, \\ H-4032 Debrecen, Egyetem tér 1. Hungary
}

(Received: January 11, 2017; accepted: May 4, 2017)

\begin{abstract}
Selenium is an essential microelement for the normal functioning of life processes. Moreover, it is a component of enzymes with antioxidant effects. However, it has the smallest window of any micronutrient between requirement and toxicity. Selenium is a regularly used element in fish feeds; moreover, enriching zooplankton with selenium to rear larvae is also a well-known technology. It is accepted that the most common starter foods of fish larvae, natural rotifers contain the smallest dosage of selenium, but providing selenium enriched Artemia sp. instead could increase survival and growth rate of fish. However, no such references are available for the red drum (Sciaenops ocellatus) larvae. Therefore, in this study, Artemia sp. was enriched with nano-selenium of verified low toxicity and easy availability in 5 treatments $(1,5,10,50,100 \mathrm{mg} / \mathrm{l} \mathrm{Se})$, and then, fish larvae were fed with four of these enriched Artemia stocks $(1,5,10,50 \mathrm{mg} / 1 \mathrm{Se})$ and a control group. At the end of the 9-day-long experiment, survival rate $(\mathrm{S})$ and growth parameters (SL, W, K-factor, SGR) of fish larvae were calculated as well as their selenium retention and glutathione peroxidase enzyme activity were analysed. It was revealed that a moderate level of selenium enrichment ( $\sim \mathrm{mg} / \mathrm{kg}$ dry matter) of Artemia sp. positively influences the rearing efficiency (i.e. survival and growth) of fish larvae, but higher dosages of selenium could cause adverse effects.
\end{abstract}

Keywords: Nano elemental selenium - red drum - Artemia sp. - enrichment - optimum

\section{INTRODUCTION}

Selenium (Se) is an essential element for the normal functioning of life processes [20]. The importance of this element was revealed in 1973 when Flohé et al. [8] and Ribeiro et al. [34] discovered that Se was an essential component of the enzyme glutathione peroxidase. Four Se-containing glutathione peroxidases are known, namely, the cytosolic (GPx1), gastrointestinal (GPx2), plasma (GPx3), and phospholipid hydroperoxidase (GPx4) [3]. Each of them is an individual selenoprotein, but all of

\footnotetext{
*Corresponding author; e-mail address: peter.juhasz@fm.gov.hu
} 
them have antioxidant effects. Thus, Se is a component of enzymes with antioxidant effects, unlike vitamins $\mathrm{E}$ and $\mathrm{C}$, which are antioxidants that function independently of enzymes [4].

Se deficit in fish can easily lead to reduced growth rate [40], increased oxidative stress [2,9] and increased mortality [9]. Although Se is essential for vertebrates [17], it has the smallest window of any micronutrient between requirement and toxicity $[5,26,32]$, however, the chemical form affects both its bioavailability and potential toxicity [38]. Se from selenomethionine has a higher retention [16, 25, 35] and bioavailability in fish [40] than selenium from selenite. Selenium toxicity is caused mainly by selenium in its ionic forms [23], which may explain why selenomethionine, that contains inert selenium until its catabolism, is less toxic than selenite and selenate. Better availability of organic forms in contrast to inorganic ones was demonstrated in Atlantic salmon (Salmo salar) [1, 25] and channel catfish (Ictalurus punctatus) [40].

According to the latest research, red elemental Se in nano-sized particles is similar in its efficiency to organic Se forms, while its potential toxicity is lower [41]. The redox potential of elemental Se is zero, it is not water-soluble and generally considered to be biologically inert, and thus its toxicity can be lower than that of other selenium forms [43]. Nano-sized elements - including $\mathrm{Se}$ - can have new characteristics, just like an expanded surface and high reactivity [15], which may contribute to their further utilization.

While feeding with lipid-enriched Artemia sp. (Crustacea, Anostraca) has been demonstrated to increase larval rearing success for many fish species $[7,11,18,22$, 44], the effects of mineral enriched Artemia sp. on larval rearing of fish is still poorly known. Hamre et al. [12] demonstrated that one of the largest nutritional differences between planktonic crustaceans (copepods in that case) and rotifers lies in their mineral composition. The largest differences could be found in case of the Se, because its levels in rotifers were more than 30 times lower than in copepods [12] and 3-8 times lower than the Se requirement of juvenile fish, equalling 0.25-0.7 mg Se kg-1 DW [30]. Furthermore, it is generally known that the mineral content of the wild-reared saltwater zooplankton is higher than that of artificially reared zooplankton [13, 28] because of the nutrient-rich seawater. Consequently, using Se enriched crustaceans (e.g. Artemia sp.) can be beneficial in the larval rearing of certain fish species.

Se requirement of fish species is different [6]; therefore, the purpose of the present study was to investigate the optimal Se enrichment level of the diet in the widely cultured red drum (Sciaenops ocellatus) larvae, which has not yet been reported. In the present study, Artemia sp. was enriched with nano-Se in 5 treatments compared to the control. Four of these enriched Artemia sp. stocks were then tested relative to the untreated control food in a 9-day-long feeding trial with red drum larvae, where survival and growth parameters (length, weight, K-factor) of fish were calculated, as well as the Se retention and the activity of the enzyme glutathione peroxidase were analysed. 


\section{MATERIALS AND METHODS}

\section{Preparation of the selenium solution and Artemia enrichment}

The solution used to enrich Artemia sp. contained nano elemental Se (60-80 nm). Its production was based on a new ascorbic acid reduction method: 2.5 litres of 2000 $\mathrm{mg} / \mathrm{l}$ selenite solution were mixed with the same amount of $10,000 \mathrm{mg} / \mathrm{l}$ ascorbic acid solution and the reduction proceeded for 30 minutes. Five litres of $1000 \mathrm{mg} / \mathrm{l} \mathrm{nano-Se}$ stock-solution were diluted for the preparation of the different solutions for the treatments.

After a 24-hour incubation period [29], newly hatched Artemia sp. (Sera, Germany) were enriched with nano-Se in 5 different concentrations $(1 \mathrm{mg} / \mathrm{l} ; 5 \mathrm{mg} / \mathrm{l} ; 10 \mathrm{mg} / \mathrm{l}$; $50 \mathrm{mg} / \mathrm{l} ; 100 \mathrm{mg} / \mathrm{l})$, compared to the control, each treatment was repeated three WWW $(n=3)$. The experiment was carried out in plastic tanks (with 41 water volume each) with a permanent light regime and $100 \%$ oxygen saturation. The salinity was 20 ppt (Sera Marin Basic sea salt, Germany) and the water temperature was constant $\left(28 \pm 1^{\circ} \mathrm{C}\right.$, Sera water heater). The 100-150 Artemia sp. larvae per ml were stocked into each tank. After 24 hours, the enriched Artemia sp. were filtered with 150 $\mu \mathrm{m}$ plankton net and stored separately until use.

\section{Experimental design}

Red drum larvae (14 d.p.h.; days post hatch) were purchased from MADAN Kibbutz (Israel) and were set for the trial after a 48 hours acclimation period. The feeding experiment was carried out in 15 separate tanks (each with 401 water volume). Four treatment groups (1 mg/1, $5 \mathrm{mg} / 1,10 \mathrm{mg} / 1,50 \mathrm{mg} / 1 \mathrm{Se})$ and controls were set up randomly in three replications $(n=3)$. Since the treatment concentration of 100 $\mathrm{mg} / \mathrm{l}$ selenium proved to be toxic even for the Artemia sp., this dosage was not tested in the feeding experiment.

The water was previously aerated and salted, then 70 fish larvae were placed in each tank (1050 larvae overall, SL: $9.3 \pm 0.4 \mathrm{~mm}$; W: $15.06 \pm 4.77 \mathrm{mg})$. Filter pipes ensured permanent ventilation and filtration, while individual heaters (Sera) regulated the temperature $\left(27 \pm 0.8{ }^{\circ} \mathrm{C}\right)$ of the salted water (15 ppt Tetra Marin sea salt). A 12-hour light periods were alternated by 12-hour dark periods during the experiment. The fish were fed ad libitum three times a day (7 AM, 1 PM and 6 PM). Dead animals and solid wastes were removed every day using a suction tube. Mortality was registered every day.

To maintain constant experimental environment, the water temperature $\left(27 \pm 0.8^{\circ} \mathrm{C}\right)$, pH (7.9-8.2), salinity ( 15 ppt) (Hanna HI98130), oxygen saturation (Hach HQ30d), $\mathrm{NO}_{3}^{-}(<8 \mathrm{mg} / \mathrm{l}), \mathrm{NO}_{2}^{-}(<0.1 \mathrm{mg} / \mathrm{l})$ and $\mathrm{NH}^{+}(<0.45 \mathrm{mg} / \mathrm{l})$ (Aquamerc Compact Laboratory, Merc) were checked every day. The oxygen saturation in the tanks was maintained at $100 \%$ by continuous aeration. 
The 9-day-long feeding trial finished with a 24-hour-long starvation period before the fish were sampled for further analysis.

\section{Growth and survival analysis}

Six larvae from each tank (18 larvae per treatment) were separated randomly for body measurements (W, SL). A digital camera (Olympus SZ51) fixed to a microscope was used to measure the standard length of larvae on a 0.100 stage micrometer microscope slide. Pictures were analysed and the length was measured with the software WinImag 1.0. Wet weight was measured with a digital scale (Precisia 240A) with the accuracy of $0.001 \mathrm{~g}$.

Survival and growth parameters were calculated as follows:

- Survival $(\mathrm{S} ; \%)=($ harvested individuals/stocked individuals $) \times 100$;

- Specific Growth Rate $(\mathrm{SGR} ; \% /$ day $)=\left(\ln \mathrm{W}_{\mathrm{f}}-\ln \mathrm{W}_{\mathrm{i}}\right) / t \times 100$, where $\mathrm{W}_{\mathrm{f}}$ is the mean weight of the harvested individuals $(\mathrm{g}), \mathrm{W}_{\mathrm{i}}$ is the mean weight of the stocked individuals $(\mathrm{g})$ and $t$ is the duration of the experiment in days;

- K-factor [39]: $\mathrm{K}=\mathrm{W} \times 100 / \mathrm{SL}^{3}$, where $\mathrm{W}$ is the wet weight (g) and $\mathrm{SL}$ is the standard length $(\mathrm{cm})$ of fish.

\section{Chemical analysis}

Seven larvae from each tank (21 larvae per treatment) were taken for enzyme activity analysis. They were placed into liquid nitrogen immediately to stop vital processes. The method of Sedlak et al. [37] was used to analyse the activity of the enzyme glutathione peroxidase.

Another six larvae from each tank (18 larvae per treatment) were separated and frozen for later selenium content analysis. The samples of enriched Artemia sp. were washed with distilled water and also kept frozen for selenium content analysis.

For measuring the moisture content, samples were dried in an oven (at a temperature of $80^{\circ} \mathrm{C}$ ) until they were oven-dry. Then, Hydride Generation Atomic Fluorescence Spectrometry (HG-AFS) was used to analyse the selenium content. Samples were prepared for measurement using wet digestion according to Kovács et al. [21]: $5 \mathrm{ml}$ of $65 \% \mathrm{HNO}_{3}$ was added to $1 \mathrm{~g}$ sample and digested for 1 hour at $60{ }^{\circ} \mathrm{C}$, then for 240 minutes at $120{ }^{\circ} \mathrm{C}$. After that, $3 \mathrm{ml}$ of $30 \% \mathrm{H}_{2} \mathrm{O}_{2}$ was added. The digested samples were diluted to $15 \mathrm{ml}$ using $3 \mathrm{M} \mathrm{HCl}$ and then filtered. Selenium content was measured using a Millennium Merlin atomic fluorescence spectrometer with following parameters: argon gases flush with the flow rate of 15 litres/minute, 40 seconds/measure, 40 seconds of washing time. The device was calibrated to the Charlau-standard before measurement, which was repeated after each 5 measurements to maintain accuracy. Three $\mathrm{M} \mathrm{HCl}$ was used for the hydride reaction, while the reductive agent was $1.4 \mathrm{~m} / \mathrm{V} \% \mathrm{NaBH}_{4}$ dissolved in $0.1 \mathrm{M} \mathrm{NaOH}$. The reagents were of analytical purity. 


\section{Statistical analysis}

Data were analysed with Microsoft Excel 2013 and SPSS for Windows 20.0 software. SGR, survival, standard length, weight, $\mathrm{K}$-factor and selenium retention were analysed with single factor ANOVA. The homogeneity of each data collection was tested with Levene's test $(p>0.05)$ and Tukey's post-hoc test $(p<0.05)$ was used to analyse pairwise differences among treatment concentrations and the control in case of a significant factor effect.

The results of the single factor ANOVA were not appropriate to estimate the optimal selenium requirement of fish because of the limited number of treatments. Thus, second degree polynomial functions were defined and regression was used to calculate optimal selenium concentration for red drum larvae [42]. During data analysis, those parameters were used, where significant result was found and also important in case of the intensive aquaculture (e.g. survival, growth). Second-degree polynoms were set using the real weight, standard length and SGR data to calculate the optimum selenium requirement of the larvae. The selenium concentration at the peak point was calculated on the basis of trend equations. The " $x$ " values belonging to highest " $y$ " were searched, which was calculated by derivation of the second-degree equation. The theoretical treatment for the highest " $y$ " value was considered as optimum treatment. Regression analysis was carried out excluding the $50 \mathrm{mg} / 1$ treatment where toxicity was proven by the results of the weight, standard length and SGR.

Pearson correlation (r) was used to investigate relationship between the selenium retention (i.e. the level of enrichment) of Artemia sp. and the red drum larvae fed on it.

\section{RESULTS}

\section{Artemia sp. enrichment}

The Se retention of Artemia sp. was significant in each treatment compared to the control group (Control $-0.0002^{\mathrm{a}} \pm 0.000 \mathrm{mg} / \mathrm{kg}$ dry matter; $1 \mathrm{mg} / \mathrm{l}-0.670^{\mathrm{b}} \pm 0.002$ $\mathrm{mg} / \mathrm{kg}$ dry matter; $5 \mathrm{mg} / 1-3.788^{\mathrm{c}} \pm 0.055 \mathrm{mg} / \mathrm{kg}$ dry matter; $10 \mathrm{mg} / \mathrm{l}-6.340^{\mathrm{d}} \pm 0.037$ $\mathrm{mg} / \mathrm{kg}$ dry matter; $50 \mathrm{mg} / 1-26.914^{\mathrm{e}} \pm 0.153 \mathrm{mg} / \mathrm{kg}$ dry matter; $100 \mathrm{mg} / \mathrm{l}$ $4.740^{\mathrm{f}} \pm 0.066 \mathrm{mg} / \mathrm{kg}$ dry matter). Se concentration of Artemia sp. increased considerably along with Se concentration of the water up to $50 \mathrm{mg} / \mathrm{l}$, but it dropped markedly at the largest treatment concentration $(100 \mathrm{mg} / \mathrm{l} \mathrm{Se})$ indicating a kind of inhibition on normal life functions of Artemia sp. For this reason, the $100 \mathrm{mg} / \mathrm{l}$ selenium treatment was not used in the fish feeding experiment (Fig. 1). 


\section{Survival, growth, K-factor and enzyme activity of fish larvae}

The survival rate of the control red drum larvae group was 57\%. Slightly increased Se content of Artemia sp. seemed to improve the vitality of fish larvae, however, only the $10 \mathrm{mg} / \mathrm{l} \mathrm{Se}$ treatment showed a significant difference at $69 \%$ survival rate. Higher nano-selenium content had no stimulatory effect on health conditions of larvae and the survival rate $(56 \%)$ in the $50 \mathrm{mg} / \mathrm{l}$ treatment equaled that of the control group (Table 2).

Nano elemental Se had a slight but generally not significant positive influence on growth parameters of fish as at concentrations up to $10 \mathrm{mg} / \mathrm{l}$ as well. The average weight of the control group was $0.095 \mathrm{~g}$. Mean fish weight increased slightly to the 5 $\mathrm{mg} / \mathrm{l}$ treatment level (average weight: $0.140 \mathrm{~g}$ ) but not significantly. On the other hand, the $50 \mathrm{mg} / \mathrm{l} \mathrm{Se}$ treatment clearly resulted in a decrease of fish growth (average weight: $0.058 \mathrm{~g}$ ), indicating a toxic effect. Similar results were obtained for standard length, K-factor and SGR, with highest index values observed in $5-10 \mathrm{mg} / \mathrm{l} \mathrm{Se}$ treatments and lowest values in the $50 \mathrm{mg} / 1$ selenium treatment (Tables 1 and 2).

The Se treatment had a slight, non-significant negative impact on the activity of the enzyme glutathione peroxidase up to $10 \mathrm{mg} / \mathrm{l} \mathrm{Se}$ concentration and a more expressed inhibitor effect at $50 \mathrm{mg} / \mathrm{l} \mathrm{Se}$ treatment concentration (Table 2).

Table 1

Influence of Artemia sp. enriched with nano-selenium on the mean $( \pm \mathrm{SD})$ growth and condition (K-factor) of red drum larvae (Sciaenops ocellatus) by the end of 9-day-long feeding trial

\begin{tabular}{|c|c|c|c|}
\hline $\begin{array}{c}\text { Treatment } \\
(\mathrm{mg} / \mathrm{l})\end{array}$ & $\begin{array}{c}\text { Weight } \\
(\mathrm{W}, \mathrm{g})\end{array}$ & $\begin{array}{c}\text { Standard length } \\
(\mathrm{SL}, \mathrm{mm})\end{array}$ & K-factor \\
\hline Control & $0.095 \pm 0.005^{\mathrm{ab}}$ & $16.7 \pm 0.5^{\mathrm{ab}}$ & $2.03 \pm 0.29^{\mathrm{NS}}$ \\
\hline 1 & $0.117 \pm 0.007^{\mathrm{a}}$ & $17.3 \pm 0.1^{\mathrm{ab}}$ & $2.30 \pm 0.20^{\mathrm{NS}}$ \\
\hline 5 & $0.140 \pm 0.018^{\mathrm{a}}$ & $18.9 \pm 0.8^{\mathrm{a}}$ & $2.07 \pm 0.12^{\mathrm{NS}}$ \\
\hline 10 & $0.106 \pm 0.034^{\mathrm{ab}}$ & $17.0 \pm 2.1^{\mathrm{ab}}$ & $2.12 \pm 0.11^{\mathrm{NS}}$ \\
\hline 50 & $0.058 \pm 0.006^{\mathrm{b}}$ & $14.6 \pm 0.2^{\mathrm{b}}$ & $1.78 \pm 0.26^{\mathrm{NS}}$ \\
\hline
\end{tabular}

Different letters mark significant differences within each column (Tukey HSD, $p<0.05$ ); NS = not significant.

Table 2

Influence of nano-selenium enriched Artemia sp. on the mean $( \pm \mathrm{SD})$ survival and specific growth rate (SGR) of red drum larvae (Sciaenops ocellatus) and on the activity of the enzyme glutathione peroxidase (GSH-px) by the end of 9-day-long feeding trial

\begin{tabular}{|c|c|c|c|}
\hline $\begin{array}{c}\text { Treatment } \\
(\mathrm{mg} / \mathrm{l})\end{array}$ & Survival $(\%)$ & SGR $(\% /$ day $)$ & $\begin{array}{c}\text { GSH-px enzyme activity } \\
(\mu \mathrm{mol} / \mathrm{g} / \mathrm{min})\end{array}$ \\
\hline Control & $57 \pm 2^{\mathrm{a}}$ & $20.22 \pm 0.64^{\mathrm{a}}$ & $28.3 \pm 1.5^{\mathrm{a}}$ \\
\hline 1 & $64 \pm 1^{\mathrm{ab}}$ & $22.29 \pm 0.86^{\mathrm{ab}}$ & $23.6 \pm 2.5^{\mathrm{ab}}$ \\
\hline 5 & $66 \pm 6^{\mathrm{ab}}$ & $24.52 \pm 1.56^{\mathrm{b}}$ & $24.8 \pm 3.0^{\mathrm{ab}}$ \\
\hline 10 & $69 \pm 4^{\mathrm{b}}$ & $22.34 \pm 1.98^{\mathrm{ab}}$ & $26.1 \pm 1.8^{\mathrm{ab}}$ \\
\hline 50 & $56 \pm 4^{\mathrm{a}}$ & $15.77 \pm 1.24^{\mathrm{c}}$ & $17.3 \pm 1.9^{\mathrm{b}}$ \\
\hline
\end{tabular}

Different letters mark significant differences within each column (Tukey HSD, $p<0.05$ ). 


\section{Se accumulation of fish larvae}

The Se retention of red drum larvae increased significantly from $2.19 \mathrm{mg} / \mathrm{kg}$ (control) to $39.24 \mathrm{mg} / \mathrm{kg}(50 \mathrm{mg} / \mathrm{l} \mathrm{Se})$ depending on the treatment concentration and proving the uptake of Se by fish from the enriched Artemia sp. feed (Figs 1 and 2).

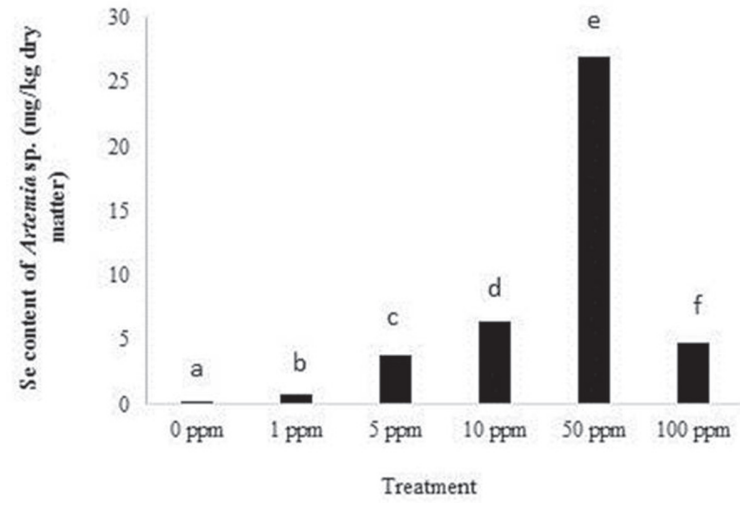

Fig. 1. Selenium retention $(+/-\mathrm{SD})$ of selenium treated Artemia sp. Different letters mark significant differences (Tukey HSD, $p<0.05$ )

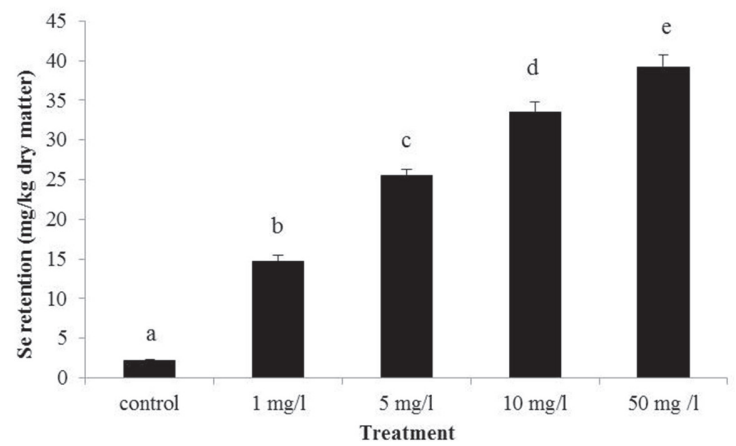

Fig. 2. Selenium retention (+/- SD) of red drum (Sciaenops ocellatus) larvae. Different letters mark significant differences (Tukey HSD, $p<0.05$ )

\section{Assessment of the optimal selenium treatment concentration}

The Se requirement of red drum larvae was calculated on the basis of the parameters, for which significant result was found. Based on these functions, significant statistical relationships were found between the considered growth parameters and the selenium treatment concentration (Fig. 3; weight: $R^{2}=0.9789$; standard length: $R^{2}=0.9911$; SGR: $\left.R^{2}=0.9694\right)$. The functions reached their maximum at $5.25 \mathrm{mg} / \mathrm{l}$ in case of weight, $5.22 \mathrm{mg} / \mathrm{l}$ in case standard length, and at $5.69 \mathrm{mg} / \mathrm{l}$ in case of SGR. 

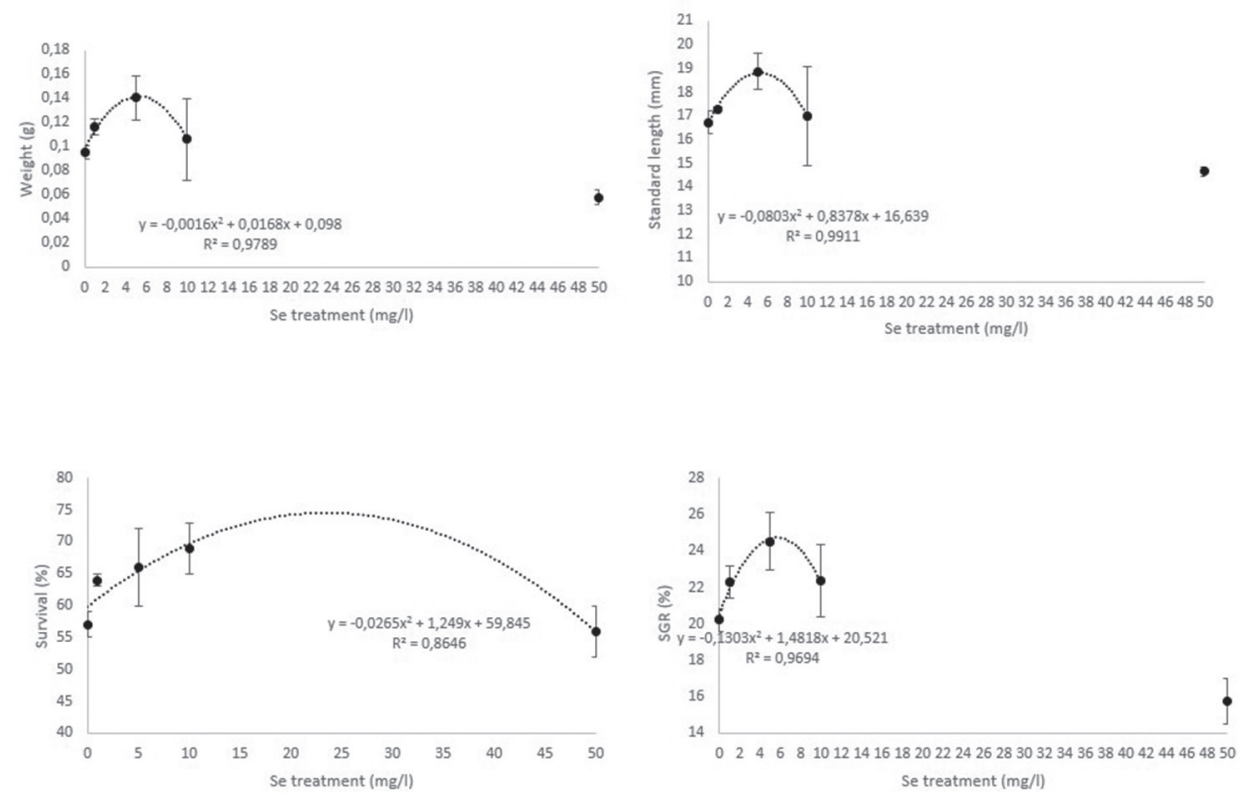

Fig. 3. Response of red drum larvae to Artemia sp. feed enriched at different selenium concentrations Regression analysis was carried out excluding the $50 \mathrm{mg} / 1$ treatment in case of weight, standard length and SGR, where toxicity was proven

The $50 \mathrm{mg} / \mathrm{l}$ treatment was also taken into account during the calculation of the regression because the optimal selenium concentration could range between 10 and $50 \mathrm{mg} / \mathrm{l}$ in case of survival rate. The polynomial functions revealed significant statistical relationship between the survival rate and the Se treatment dosages $\left(R^{2}=0.8646\right)$. The peak was reached at $23.57 \mathrm{mg} / \mathrm{l} \mathrm{Se}$ treatment concentration, which is a substantially higher value than that of derived based on the growth parameters. To define Se optimum of the red drum larvae, the lower values were taken into account, regarding the possibility of toxicity in higher Se concentrations.

\section{DISCUSSION}

In aquaculture fish larvae are still very often reared on natural diet like rotifers and small planktonic crustaceans. However, these food organisms generally contain a suboptimal amount of selenium, and therefore, rearing efficiency (i.e. survival and growth rates) of fish larvae can be lower than required. In this study, we tested whether Artemia sp. could be effectively enriched with Se by maintaining them in Se solution of different concentrations, and whether these treated preys could improve the survival and growth rate of red drum larvae. Our results revealed that Artemia sp. accumulate Se very effectively from water and the accumulation rate was propor- 
tional to the Se concentration of the water. Furthermore, results also proved some positive influence of this enriched food for the survival and growth rate of fish larvae but only up to moderate selenium concentrations.

Contrary to Artemia sp., there are several examples for the influence of rotifers enriched with $\mathrm{Se}$ on fish development under experimental conditions. For instance, Hamre et al. [12] performed an experiment on Atlantic cod (Gadus morhua, L.) and observed a $32 \%$ higher survival rate in fish fed on rotifers enriched with $7 \mathrm{mg} / \mathrm{l}$ sodium selenite and $400 \mathrm{mg} / \mathrm{l}$ sodium iodide, compared to the control group, but cod larvae showed a slight decrease in growth parameters. In our study, red drum larvae kept on Se enriched Artemia sp. diet showed also a slight improvement in their survival, especially in the $10 \mathrm{mg} / \mathrm{l}$ treatment. On the other hand feeding trials with senegalese sole (Solea senegalensis, Kaup) [34] and with malabar grouper (Epinephelus malabaricus, Bloch and Schneider) [24] larvae failed not show any significant Se related difference in their survival rate. Growth parameters (i.e. increase in SL and W, and SGR) of red drum larvae were the best when they were fed with $5 \mathrm{mg} / \mathrm{l}$ selenium treated Artemia sp. that accumulated $3.788 \mathrm{mg} / \mathrm{kg}$ (dry matter) selenium. Similarly, Kim et al. [19] noticed an improved growth rate in red seabream (Pagrus major, Temminck and Schlegel) when they were provided enriched rotifers of $2.2 \mathrm{mg} / \mathrm{kg}$ (dry matter) Se content.

In accordance with the results of Hamre et al. [12], Se treatments did not have significant impact on the activity of the enzyme glutathione peroxidase, except for the inhibitor effect observed at the highest applied dosage of $50 \mathrm{mg} / \mathrm{l}$. Ribeiro et al. [34] similar reported results when analysing the impact of zooplankton enriched with $\mathrm{Se}$ on enzymatic activity of senegalese sole.

Several authors $[10,14,24]$ calculated GSH-px enzyme activity as a key index to define selenium requirement of fish. In these experiments, the maximum of enzyme activity was considered as the sign of the optimal level of selenium requirement. In our study, however, the maximum enzyme activity was observed in the control group which contradicted the results of the survival and growth analyses. Accordingly, we assessed optimal Se treatment concentration of Artemia sp. for red drum larvae based on the maximum of survival rate and growth parameters. It was revealed that the optimal treatment dosage for Artemia sp. enrichment ranged between $5.22 \mathrm{mg} / \mathrm{l}$ (based on SL), 5.25 (based on W increments) and $5.69 \mathrm{mg} / 1 \mathrm{Se}$ in the water (based on SGR). These treatment levels corresponded to 3.95 and $4.30 \mathrm{mg} / \mathrm{kg}$ (dry matter) accumulated Se in the zooplankton for the red drum, which substantially exceed the $0.25-0.7 \mathrm{mg} / \mathrm{kg}$ (dry matter) dosage range recommended by other authors for different fish species [24, 30,33]. On the other hand, Penglase et al. [31] estimated nearly as high Se dosage optimum, ranging between 1.4 and $3 \mathrm{mg} / \mathrm{kg}$ (dry matter), for the Atlantic cod larvae in zooplankton than our values, which level is three times higher than those generally available in hatcheries' practice. The estimated optimum of 4 $\mathrm{mg} / \mathrm{kg}$ (dry matter) Se content of Artemia sp. is similar to the natural Se content of copepods as well [12].

Regarding all the production parameters that were investigated in the experiment it was formed that the selenium intake from the Se enriched zooplankton $(26.90 \mathrm{mg} /$ 
$\mathrm{kg}$ Se in DW) in group $50 \mathrm{mg} / \mathrm{l}$ caused toxic effect. The reduced growth is the sign of excessive intake of Se $[14,16,24]$, which was confirmed by the results obtained in group $50 \mathrm{mg} / \mathrm{l}$ as the lowest length and weight as well as the worst condition of fish larvae observed. In the group $10 \mathrm{mg} / 1$ reduced growth was also observed, which suggests the high intake of the microelements. Regarding the accumulated Se in the body of the red drum larvae, significant differences were found between each treatment. Close relationship was found by Pearson correlation $(r=0.765)$ between the level of the accumulated selenium in the zooplankton and the selenium content of the fish larvae which suggests that Se was successfully incorporated into the body of fish. Based on it foregoing, it can be clearly determinated that the nano-sized elemental Se can be toxic to the fish, both in the organic and inorganic form [27].

In conclusion, based on the results of the feeding trial, Artemia sp. enriched with nano-Se had a positive impact on the efficiency of red drum larvae rearing. According to our estimates, the optimal Se content of the feed could be $4 \mathrm{mg} / \mathrm{kg}$ (dry matter) for the red drum, which requires an enrichment treatment of Artemia sp. in $5 \mathrm{mg} / \mathrm{l} \mathrm{Se}$ solution for one day.

\section{ACKNOWLEDGEMENTS}

This research was performed in the frame of the TÁMOP 4.2.4. A/2-11-1-2012-0001 "National Excellence Program - Elaborating and operating an inland student and researcher personal support system" project. The project was supported by the European Union and co-financed by the European Social Fund.

\section{REFERENCES}

1. Bell, J. G., Cowey, C. B. (1989) Digestibility and bioavailability of dietary selenium from fishmeal, selenite, selenomethionine and selenocystine in Atlantic salmon (Salmo salar). Aquaculture 81, $61-68$.

2. Bell, J. G., Cowey, C. B., Adron, J. W., Pirie, B. J. S. (1987) Some effects of selenium deficiency on enzyme activities and indices of tissue peroxidation in Atlantic salmon parr (Salmo salar). Aquaculture 65, 43-54.

3. Brigelius-Flohe, R. (1999) Tissue-specific functions of individual glutathione peroxidases. J. Free Radic. Biol. Med. 27, 951-965.

4. Burk, R. F. (2002) Selenium an antioxidant nutrient. Nutr. in Clinical Care 5, 75-79.

5. Chassaigne, H., Chéry, C. C., Bordin, G., Rodriguez, A. R. (2002) Development of new analytical methods for selenium speciation in selenium-enriched yeast material. J. Chromatogr. A. 976, 409422.

6. Davis, D. A., Gatlin III, D. M. (1996) Dietary mineral requirements of fish and marine crustaceans. Rev. Fish. Sci. 4, 75-99.

7. Estevez, A., Kanazawa, A. (1996) Fatty acid composition of neural tissues of normally pigmented and unpigmented juveniles of Japanese flounder using rotifer and Artemia enriched in n y 3 HUFA. Fisheries Sci. 62, 88-93.

8. Flohé, L., Gunzler, W. A., Schock, H. H. (1973) Glutathione peroxidase: A selenoenzyme. FEBS Lett 32,132 . 
9. Gatlin III, D. M., Poe, W. E., Wilson, R. P. (1986) Effects of singular and combined dietary deficiencies of selenium and vitamin $\mathrm{E}$ on fingerling channel catfish (Ictalurus punctatus). J. Nutr. 116, 1061-1067.

10. Gatlin III, D. M., Wilson, R. P. (1984) Dietary selenium requirement of fingerling channel catfish. J. Nutr. 114, 627-633.

11. Hafezieh, M., Salleh Kamarudin, M., Roos Bin Saad, C., Kamal Abd Sattar, M., Agh, N., Hosseinpour, H. (2009) Effect of enriched artemia urmiana on growth, survival and composition of larval persian sturgeon. Turk. J. Fish. Aquat. Sc. 9, 201-207.

12. Hamre, K., Mollan, T. A., Sæle, Ø., Erstad, B. (2008) Rotifers enriched with iodine and selenium increase survival in Atlantic cod (Gadus morhua) larvae. Aquaculture 284, 190-195.

13. Hamre, K., Opstad, I., Espe, M., Solbakken, J., Hemre, G. I., Pittman, K. (2002) Nutrient composition and metamorphosis success of Atlantic halibut (Hippoglossus hippoglossus, L.) larvae fed natura zooplankton or Artemia. Aquaculture Nutr. 8, 139-148.

14. Hilton, J. W., Hodson, P. V., Slinger, S. J. (1980) The requirement and toxicity of selenium in rainbow trout (Salmo gairdneri). J. Nutr. 110, 2527-2535.

15. Huang, B., Zhang, J., Hou, J., Chen, C. (2003) Free radical scavenging efficiency of nano-Se in vitro. J. Free Radic. Biol. Med. 35, 805-813.

16. Jaramillo, F., Peng, L., Gatlin, D. (2009) Selenium nutrition of hybrid striped bass (Morone chrysops $\times$ M. saxatilis) bioavailability, toxicity and interaction with vitamin E. Aquaculture Nutr. 15, 160-165.

17. Johansson, L., Gafvelin, G., Arnér, E. S. J. (2005) Selenocysteine in proteins - properties and biotechnological use. BBA General Subjects. 1726, 1-13.

18. Kamaszewski, M., Ostaszewska, T., Prusińska, M., Kolman, R., Chojnacki, M., Zabytyvskij, J., Jankowska, B., Kasprzak, R. (2014) Effects of Artemia sp. enrichment with essential fatty acids on functional and morphological aspects of the digestive system in Acipenser gueldenstaedtii Larvae. Turk. J. Fish. Aquat. Sc. 14, 929-938.

19. Kim, S.-K. , Kim, K.-G., Kim, K.-D., Kim, K.-W., Son, M.-H., Rust, M., Johnson, R. (2014) Effect of dietary taurine levels on the conjugated bile acid composition and growth of juvenile Korean rockfish Sebastes schlegeli (Hilgendorf) Aquacult. Res. 46: 2768-2775.

20. Kohrle, J. (2004) Selenium in biology and medicine - further progress and increasing interest. J. Trace Elem. Med. Biol. 18, 61-63.

21. Kovács, B., Prokisch, J., Győri, Z., Kovács, A. B., Palencsar, A. (2000) Analytical methods and quality assurance: studies on soil sample preparation for inductively coupled plasma atomic emission spectrometry analysis. Commun. Soil Sci. Plan. 31, 1949-1963.

22. Leger, P., Bengston, D. A., Simpson, K. L., Sorgeloos, P. (1986) The use and nutritional value of Artemia as a food source. In: Barnes, M. (ed.) Oceanogr. Mar. Biol. Annual Reviews Vol 24. Aberdeen Univ. Press, Aberdeen, Scotland. pp. 521-623.

23. Lemly, A. D. (2002) Symptoms and implications of selenium toxicity in fish: the Belews Lake case example. Aquat. Toxicol. 57, 39-49.

24. Lin, Y. H., Shiau, S. Y. (2005) Dietary selenium requirements of juvenile grouper, Epinephelus malabaricus. Aquaculture 250, 356-363.

25. Lorentzen, M., Maage, A., Julshamn, K. (1994) Effects of dietary selenite or selenomethionine on tissue selenium levels of Atlantic salmon (Salmo salar). Aquaculture 121, 359-367.

26. Maier, K. J., Knight, A. W. (1994) Ecotoxicology of selenium in freshwater system. In: Ware, G. W. (ed.) Rev. Environ. Contam. Toxicol. 134, Springer-Verlag, New York, pp. 31-48.

27. McAdam, P. A., Levander, O. A. (1987): Chronic toxicity and retention of dietary selenium fed to rats and D- or L selenomethionine, selenite or selenate. Nutr. Res. 7, 601-610.

28. Naess, T., Germain-Henry, M., Naas, K. E. (1995) First feeding of Atlantic halibut (Hippoglossus hippoglossus) using different combinations of Artemia and wild zooplankton. Aquaculture 130, 235-250.

29. Nguyen, V. T., Satoh, S., Haga, Y., Fushimi, H., Kotani, T. (2008) Effect of zinc and manganese supplementation in Artemia on growth and vertebral deformity in red sea bream (Pagrus major) larvae. Aquaculture 7, 184-192. 
30. NRC (1993) Nutrient Requirements of Fish. National Academy Press, Washington, DC, pp. 62-63.

31. Penglase, S., Nordgreen, A., Meeren, T. van der, Olsvik, P. A., Sæle, Ø., Sweetman, J. W., Baeverfjord, G., Helland, S., Hamre, K. (2010) Increasing the level of selenium in rotifers (Brachionus plicatilis 'Cayman') enhances the mRNA expression and activity of glutathione peroxidase in cod (Gadus morhua L.) larvae. Aquaculture 306, 259-269.

32. Polatajko, A., Jakubowski, N., Szpunar, J. (2006) State of the art report of selenium speciation in biological samples. J. Anal. At. Spectrom. 21, 639-654.

33. Ribeiro, A. R. A., Ribeiro, L., Dinis, M. T., Moren, M. (2011) Protocol to enrich rotifers (Brachionus plicatilis) with iodine and selenium. Aquacult. Res. 42, 1737-1740.

34. Ribeiro, A. R. A., Ribeiro, L., Sæle, Ø., Dinis, M. T., Moren, M. (2012) Iodine and selenium supplementation increased survival and changed thyroid hormone status in Senegalese sole (Solea senegalensis) larvae reared in a recirculation system. Fish Physiol. Biochem. 38, 725-734.

35. Rider, S. A., Davies, S. J., Jha, A. N., Clough, R., Sweetman, J. W. (2010) Bioavailability of co-supplemented organic and inorganic zinc and selenium sources in a white fishmeal based rainbow trout (Oncorhynchus mykiss) diet. J. Anim. Physiol. Anim. Nutr. 94, 99-110

36. Rotruck, J. T., Pope, A. L., Ganther, H. E., Swanson, A. B., Hafeman, D. G., Hoekstra, W. G. (1973) Selenium: biochemical role as a component of glutathione peroxidase. Science 179, 585-590.

37. Sedlak, J., Lindsay, R. H. (1968) Estimation of total, protein-bound, and nonprotein sulfhydryl groups in tissue with Ellman's reagent. Anal. Biochem. 25, 192-205.

38. Suhajda, Á., Hegóczki, J., Janzsó, B., Pais, I., Vereczkey, G. (2000) Preparation of selenium yeasts I. Preparation of selenium-enriched Saccharomyces cerevisiae. J. Trace Elem. Med. Biol. 14, 43-47.

39. Wakeman, J. M., Ramsey, P. R. (1985) A survey of population characteristic for red drum and spotted sea trout in Louisiana. Gulf Res. Ref. 8, 1-8.

40. Wang, C., Lovell, R. T. (1997) Organic selenium sources, selenomethionine and selenoyeast, have higher bioavailability than an inorganic selenium source, sodium selenite, in diets for channel catfish (Ictalurus punctatus). Aquaculture 152, 223-234.

41. Wang, H., Zhang, J., Yu, H. (2007) Elemental selenium at nano size possesses lower toxicity without compromising the fundamental effect on selenoenzymes: comparison with selenomethionine in mice. Free Radic. Biol. Med. 42, 1524-1533.

42. Zeitoun, I. H., Ullrey, D. E., Magee, W. T. (1976) Quantifying nutrient requirements of fish. J. Fish. Res. Board. Can. 33, 167-172.

43. Zhang, J., Wang, H., Yan, X., Zhang, L. (2005) Comparison of short-term toxicity between nano-Se and selenite in mice. Life Sci. 76, 1099-1109.

44. Zheng, F., Takeuchi, T., Yoseda, K., Kobayashi, M., Hirokawa, J., Watanabe, T. (1996) Requirement of larval cod for arachidonic acid, eicosapentaenoic acid, and docosahexaenoic acid using enriched Artemia nauplii. Nippon Suisan Gakk. 62, 669-676. 